\title{
LinkedIn — portal społecznościowy dla profesjonalistów. Część I
}

\author{
Andrzej L. Komorowski
}

\section{Linkedln — social media for professionals. Part I}

Wielką popularność w ostatnich latach zdobyły tak zwane portale społecznościowe. Nawet osoby niezainteresowane internetem słyszały z pewnością o Facebooku czy Twitterze. W tradycyjnych środkach przekazu regularnie pojawiają się odwołania do profilu na Facebooku albo do komentarza umieszczonego przez urzędnika państwowego na Twitterze (sic!). Czym są te popularne portale społecznościowe? Ich funkcjonowanie opiera się na dobrowolnym rejestrowaniu się zainteresowanych i tworzeniu przez nich swoich prywatnych stron w obrębie portalu (tzw. profili). Profile mogą tworzyć zarówno osoby fizyczne, instytucje, jak też byty zupełnie nieokreślone (np. profil o nazwie „Obama musi odejść"). Profile są dotępne publicznie, a w zależności od tego, czy mamy swój profil oraz czy jesteśmy uznani przez właściciela danego profilu za znajomego, zyskujemy dostęp do części lub całości informacji. Zawartość profilu jest kształtowana wyłącznie przez jego właściciela. Dlatego na portalu Facebook, utworzonym w założeniu jako platforma pozawalająca utrzymywać kontakt ze znajomymi, są głównie informacje o zainteresowaniach, życiu rodzinnym i towarzyskim. Z punktu widzenia osoby ceniącej swój czas i szukającej w internecie narzędzi pomagających w pracy naukowej i zawodowej większość tego rodzaju portali nie ma zbyt wiele do zaproponowania.

W 2003 roku utworzono nowy portal społecznościowy oparty na podobnych co wspomniane zasadach, ale zwrócony do innego odbiorcy. Portal Linkedln (www.linkedin.com) został stworzony z myślą o osobach pragnących w prosty sposób utrzymywać kontakty ze współpracownikami oraz wymieniających informacje zawodowe z innymi specjalistami w swojej dziedzinie. Można zatem powiedzieć, że w dużej mierze został stworzony z myślą o lekarzach.

Aby ułatwić poruszanie się po portalu LinkedIn, najlepiej już podczas pierwszej wizyty dokonać darmowej rejestracji. Jest to operacja bardzo prosta, zwłaszcza że portal Linkedln od 2012 roku jest dostępny także w języku polskim. Do rejestracji potrzebne jest jedynie podanie adresu e-mail oraz hasła. W przypadku, gdybyśmy zapomnieli, jakiego hasła użyliśmy, portal może przesłać nam przypomnienie hasła na podany adres e-mailowy. Podczas pierwszej rejestracji portal zaproponuje zaimportowanie danych z książki adresowej. Jest to ciekawa opcja, pozwalająca na automatyczne rozesłanie do wszystkich osób umieszczonych w naszej skrzynce adresów e-mailowych zaproszenia do nawiązania kontaktu z nami w obrębie portalu Linkedln. Po udanej rejestracji portal automatycznie utworzy nasz profil. Możemy od razu zabrać się za uzupełnianie go informacjami o sobie albo rozpocząć przeszukiwania zasobów Linkedln — obecnie jest to około 225 milionów profili.

Na głównej stronie naszego profilu (ryc. 1) w prawym górnym rogu zaznaczono wyszukiwarkę składającą się z dwóch pól: w pierwszym umieszczono słowo "osoby", a w drugim — "szukaj". Klikając na „osoby”, zobaczymy szereg innych kryteriów, pod jakimi można prowadzić wyszukiwanie kontaktów. Po wybraniu kryterium w polu „szukaj” wpisujemy wybrane słowo kluczowe i klikamy na lupę lub wciskamy klawisz „enter". Wpisując imię i nazwisko poszukiwanej osoby (np. Jana Kowalskiego), otrzymamy zestaw 794 profili Janów Kowalskich dostępnych w portalu Linkedln. Wyszukiwania można oczywiście prowadzić w sposób bardziej precyzyjny. Warto zwrócić uwagę, że większość nazw instytucji, które zobaczymy na dowolnym profilu po wskazaniu ich myszką, zmieni kolor (zatem jest hiperłączem).

Dla ilustracji przyjmijmy, że autor artykułu poszukuje kolegi, z którym przebywał na stypendium na Uniwersytecie w Antwerpii. Obok zdjęcia widocznego na profilu głównym (ryc. 1) zobaczymy kilka odsyłaczy (hiperłączy). Klikając na tekst „wykształcenie”, zostaniemy przekierowani na część profilu dotyczącą kariery uniwersyteckiej. Zanim to zrobimy, zwróćmy jednak uwagę, że tuż obok znajduje się hiperłącze do jednego z elementów wykształcenia, w tym wypadku do Uniwersytetu w Antwerpii. Klikając na to hiperłącze, uzyskujemy dostęp do informacji o profilach studentów tego Uniwersytetu. Ponieważ kliknęliśmy na hiperłącze 


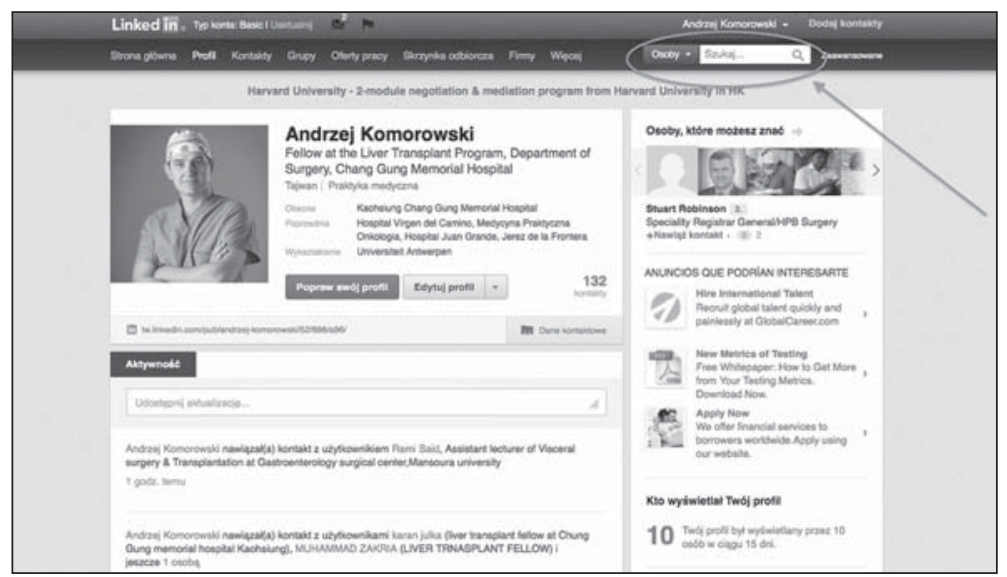

Rycina 1. Strona główna z profilem użytkownika. Zaznaczano okienko wyszukiwarki

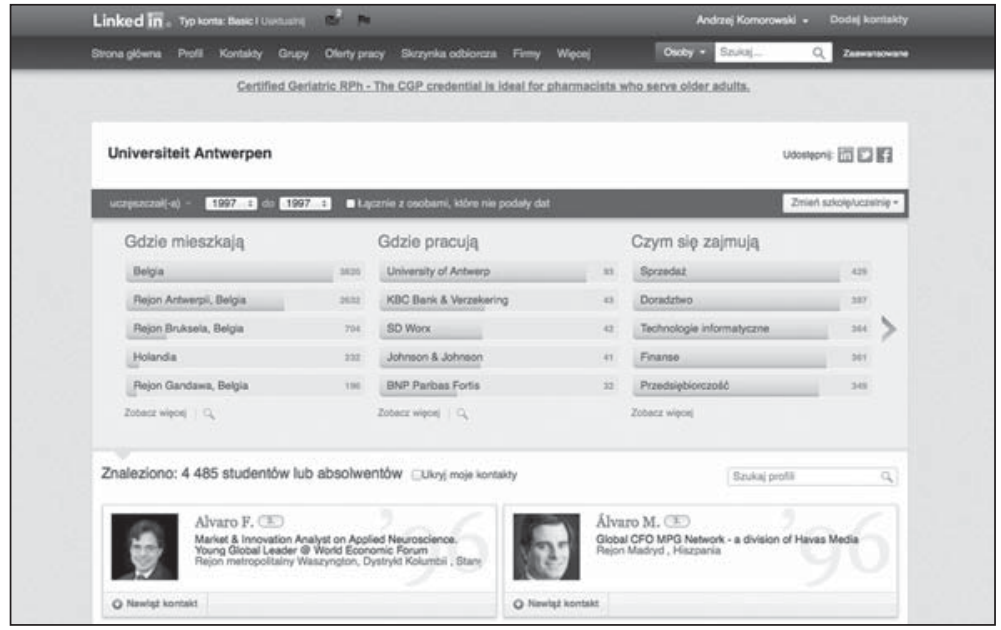

Rycina. 2. Wyniki poszukiwania użytkowników portalu studiujących w 1997 roku na Uniwersytecie w Antwerpii

z konkretnego profilu, portal automatycznie ustawił lata studiów na takie same, jakie figurowały na poprzednio oglądanym profilu. Ponieważ autor niniejszego tekstu przebywał na Uniwersytecie w Antwerpii w 1997 roku, na wyświetlonej stronie ukazały się profile 4485 absolwentów tego Uniwersytetu, którzy studiowali w tym roku oraz utworzyli swoje profile na Linkedln (ryc. 2). Portal od razu zaproponował też kilka innych kryteriów wyszukiwania: zwróćmy uwagę, że profile zostały posegregowane według kraju obecnego zatrudnienia, instytucji, wykonywanego zawodu itp. Wracając do naszych poszukiwań - klikając na interesujący nas kierunek studiów („medycyna”), uzyskujemy 125 profili. Następnie z menu "posiadane umiejętności" wybieramy "chirurgia”, co daje nam 18 osób. Ostatnia część wyszukiwarki („sieć kontaktów") informuje, jak wybrana przez nas grupa jest powiązana z naszymi kontaktami w portalu Linkedın.
W prezentowanym przykładzie widzimy, że spośród wyselekcjonowanych 125 osób studiujących medycynę w 1997 roku na Uniwersytecie w Antwerpii, chirurgią zajmuje się 18 osób, z których 2 to kontakty drugiego stopnia (to znaczy są kontaktami jednego z moich znajomych na Linkedln). W każdym momencie poszukiwań przesunięcie ekranu w dół pozwala nam zobaczyć podstawowe informacje o wyselekcjonowanych osobach. Jeżeli spojrzymy na dół ekranu po zakończeniu poszukiwania, zobaczymy informacje o dwóch kolegach z Uniwersytetu w Antwerpii. Pozostaje tylko przypomnieć sobie, czy to właśnie nasi znajomi ze stypendium, i kliknąć w opcję „nawiąż kontakt", po czym czekać na ich odpowiedź.

\section{Dr n. med. Andrzej L. Komorowski}

Liver Transplant Program, Department of Surgery, Chang Gung Memorial Hospital-Kaohsiung Medical Center, Chang Gung University College of Medicine, Kaohsiung, Tajwan e-mail:z5komoro@cyf-kr.edu.pl 